\title{
Identification of Economic Learning Resources Based on Ecopedagogy
}

\author{
Case Study on the Sago Industry in Pemakuan Village
}

\author{
Dwi Atmono, Muhammad Rahmattullah, Sri Setiti \\ Economic Education Department, \\ Faculty of Teacher Training and Education \\ Universitas Lambung Mangkurat \\ Banjarmasin, Indonesia \\ dwiatmono@ymail.com
}

\begin{abstract}
The utilization of the environment as a source for economic learning based on eco-pedagogy is an alternative way to internalize students' understanding of economic concept with environmental awareness. The Sago Industry in Pemakuan Village is an example of community's economic activities which are full of environmental issues in their daily practice. This study is aimed to identify economic learning resources based on ecopedagogy at Sago Industry in Pemakuan Village. This study used case study method. The objects of this study are the various activities of the society in Sago Industry. Data collected through field observation. Data were analyzed by qualitative descriptive technique. The results of the research indicate that several sources for economic learning based on eco-pedagogy in Sago Industry include: People habit in choosing the kind of work, the people who are involved in sago industry, production, distribution, and consumption activities, and financial management. These learning resources can be added in various economic contents including basic concepts of economics, economic system, economic agents, equilibrium and market structure, also accounting concept.
\end{abstract}

Keywords - Learning Resources, Economy, Ecopedagogy

\section{INTRODUCTION}

Environmental problems are fueled by rapid population growth. Massive increases in population are indeed needed in the form of settlement land, food and the development of various forms of livelihood that exploit nature in excess. All these cause environmental problems such as floods in the rainy season, dry season drought, landslides, forest fires, potentials, technological failures, and social conflicts. The balance of the relationship between man and nature as a lifesupport has fallen natural boundaries to support it. Damaged environments cannot work it function in support of life, so that will affect the quality of life itself.

The idea of sustainability is becoming a current issue in the country's development. Environmental degradation as an impact of industrialization gives greater harm than benefits to human life. People start thinking instantly and demanding short-term profits by using all the resources to meet their needs. The low response to environmental sustainability supported by the idea of capitalism makes people deny the importance of the sustainability of their next generation.
Education has an important role to play in raising public awareness of sustainability issues. Ref [1] explains that in general, research shows that basic education is the key to a nation's ability to develop and achieve sustainability targets. Research has shown that education can improve agricultural productivity, improve the status of women, reduce population growth rates, improve environmental protection, and generally improve living standards. Education as an institution that transforms excellent values and cultures have a very important role to foster morality, responsibility, discipline, and social solidarities in the form of spiritual and social intelligence. Education is believed to have a strategic role to foster environmental awareness, values, morality, and skills that support sustainable development, which in turn can create effective behaviors to participate in realizing environmental sustainability.

In connection with these conditions, educational process based eco-pedagogy in developing ecological awareness and character is a strategic effort to build a new paradigm to raise awareness about the importance of nature through [2]. In practice, an eco-pedagogy approach can be included in a variety of subjects includes Economics subject in high school curriculum. Ref [3] stated that the competence of Economics subjects in high school is that "students can become citizens who have the awareness, understanding, and ability to manage natural resources and create opportunities to fulfill the varied needs with limited resources through production, consumption, and distribution in the context of the devotion to the nation and the homeland by utilizing technology wisely, confident, and with great character. For more contextual learning, the teacher is expected to use the environment as a source of learning, for example, traditional markets, cooperatives, creative industries, marine resources, coastal, forest, etc. Also, teachers are also expected to utilize information and communication technology (ICT), textbooks, student worksheets, and other relevant references as learning resources, and can be enriched with local contexts by environmental conditions.

Previous research explained that the utilization of the environment is in the awareness of the students about the lesson of preserving the environment [4]. It indicates that the local environment can also help student to get better 
understanding about economic concept and environmental awareness in the same time. It also will help economic teacher to provide connected learning resources for several related economic contents in classroom.

Sago Industry in PemakuanVillage is an example of environmental based industry that exists in South Kalimantan since many years ago. Lots of activities and people included in this industry, and it is interesting to learn these things as learning resources for economic subject. The linked of environment and economic activities with sustainability issue can be interesting subject to explore the needs of learning resources for economic subject.

This study aims to identify economic learning resources based on eco-pedagogy at Sago Industry in Pemakuan Village. Through this research is expected to be recognized various forms of learning resources relevant to economic learning needs. It is also expected to map the relevance of existing learning resources with economic contents that taught to high school students.

Learning is an active engagement with information, where student needs to understand about what, how, and why: central ideas, concepts, facts, processes of inquiry, and argument of a discipline [5]. Access to information and knowledge are the fundamental right of every human, but this is not always achieved without limitations [6]. The closest learning resources around student's daily life can be effective tools to achieve the purpose of learning itself.

Ref [7] mentioned, learning resources are all sources such as messages, people, materials, tools, techniques, and backgrounds that used as a source of learners for learning activities and can improve the quality of learning. AECT in reference [8] divides learning resources on learning resources by design and learning resources by utilization. Ref [9] stated that for effective teaching and learning, textbooks and resource materials are basic tools, their absence or inadequacy makes teachers handle subjects abstractly, portraying it a dry and non-exciting. It is also important to have appropriate personnel for instructional materials and physical facilities to support educational effort. Ref[10] arguments of actual objects and phenomena and written descriptions includes scientific, scholarly, reference, and methodological teaching aids, as well as textbooks, books of problems and exercises, books for recording.

Ecopedagogy is a critical approach to teaching and learning which connects environmental and social problems [11]. Ref [12] stated that the fundamentals of the ecopedagogy include protection of nature (natural ecology), the impact of the human societies upon nature (social ecology) as well as the influence over civilization and economic, social and cultural composition (integrated ecology) therefore, essentially it promotes respect for nature, human, culture, and diversity. Local environment as learning resources take principal role to applied learning with eco-pedagogy approach.

Based on the principle of it development, eco pedagogicbased learning emphasizes the development of material that is not only limited to something that is textual but needs to be developed through a contextual approach. This means that essential learning must be developed by using resources and media within the context of the learner's life so that learners can constructs knowledge significantly. Based on this, learning should be based on an interdisciplinary approach to enrich the knowledge and understanding of learners comprehensively. Also, eco pedagogic-based education is oriented towards the attainment of a full understanding of the essence of human nature and essential relationships, thus implicating the growth of critical awareness and awakening of learners' character [2].

\section{METHOD}

This study uses the qualitative approach. The focus of this research is to identify the sources of economic learning based on eco-pedagogy on sago industry in Pemakuan Village. This study used case study method. The objects of this study are the various activities of the society in Sago Industry. Data collected through field observation. Data were analyzed by qualitative descriptive technique.

\section{RESULTS AND DISCUSSION}

Pemakuan Village is a village located in Sungai Tabuk Subdistrict, Banjar District, South Kalimantan Province. The rumbia tree is one of the natural potentials found in Pemakuan, from generation to generation, the surrounding community utilizes the tree for sago production and uses leaf of rumbia into their house roofs.

Sago production in Pemakuan Village is processed in a special place usually on the edge of the river called "wantilan." The owner and workers of sago processing industry are coming from Pemakuan Village. They used traditional method and utilize the natural surroundings. After processing sago finished, the owner will sell and distribute the sago through the collectors or local consumers.

Based on the observations, there are some community activities in sago industry in Pemakuan Village which can be used as sources for economic learning, i.e.:

\section{A. People's habits in choosing the kind of work}

The habits of people in choosing a job are one of the learning resources that suitable for economic learning. Basically, Pemakuan Village is an agricultural area. Most of the inhabitants are farmers or work in other peoples' fields. Sago industry was cultivated by farmers, especially those with large capital. Farmers, who have spare time, will work in sago fabric either as the owner or daily workers.

\section{B. People who are involved in sago industry}

Those are several community groups involved in sago processing industry, i.e.:

- Owner and daily workers. Owners and daily workers are people involved in sago production activities. The owner is a capital owner who also sometimes involves himself as a worker. Workers are local people or small farmers working to produce sago with daily paid wages. 
- Collectors. The collectors are the ones who buy sago from the producers and then resell them to other buyers. The collectors can position themselves as early consumers as well as distributors in the sago industry

- Buyer. The buyer is the ultimate consumer who buys sago for various needs. There are buyers coming from neighboring communities as well as from other regions. They use sago for various needs, especially for consumption in the form of processed food.

\section{Production, distribution and consumption activities}

- The making process of sago. The making process of sago involves a variety of activities both from the preparation of raw materials, processing, until the storage of unsold sago. All of these activities involve various parties from owners, workers, to the owners of wantilan. This activity also requires knowledge of production management from business owners.

- The distribution of sago. The distribution of sago associated with the sale of sago either to direct buyers or other distributors. Sago distribution requires special skills related to sales, purchasing, transportation, learning, risk management, standardization and market information. It is aimed to obtain maximum profit from production.

- The target market. The sago industry required skills in determining the target market of consumers who will buy sago. Sago producers should be able to read the situation about the needs of sago in the community both from the aspect of the number, target market, and the right price to obtain maximum profit.

- Supply and demand. Supply and demand process occurs on the resulting sago produce. There is a price agreement before sago changes hands to the buyer. Supply and demand also occur in the determination of labor costs or production wages.

\section{Financial management}

Sago business owners have an interesting financial management system to be learned. They define traditional cost and profit calculations without using modern accounting systems. This activity can also be used as a learning resource for economic subjects.

The mapping of economic contents for high school is described as follows [3]:
TABLE I. THE MAPPING OF ECONOMIC CONTENTS FOR HIGH SCHOOL

\begin{tabular}{|c|c|}
\hline Grade & Economic contents include \\
\hline $\begin{array}{l}10^{\text {th }} \\
\text { Grade }\end{array}$ & $\begin{array}{l}\text { a. The basic concept of economics, } \\
\text { b. Economic problems in the economic system, } \\
\text { c. The role of economic actors in economic activities, } \\
\text { d. Market equilibrium and structure, } \\
\text { e. Central banks, payment systems and payment } \\
\text { f. Finstruments, } \\
\text { g. Mancial services institutions in the Indonesian } \\
\text { h. The concept of business entities in the Indonesian } \\
\text { i. Cooperation in the Indonesian economy }\end{array}$ \\
\hline $\begin{array}{l}\text { 11th } \\
\text { Grade }\end{array}$ & $\begin{array}{l}\text { a. Concepts and methods of calculating national income, } \\
\text { b. The concept of economic growth and economic } \\
\text { development and the problems and how to overcome } \\
\text { them, } \\
\text { c. Employment issues in economic development, } \\
\text { d. Price index and inflation, } \\
\text { e. Monetary policy and fiscal policy, } \\
\text { f. APBN and APBD in economic development, } \\
\text { g. Taxation in economic development, } \\
\text { h. International trade concepts and policies, } \\
\text { i. International economic cooperation }\end{array}$ \\
\hline $\begin{array}{l}12^{\text {th }} \\
\text { Grade }\end{array}$ & $\begin{array}{l}\text { a. Accounting as an information system, } \\
\text { b. The concept of basic equations of accounting, } \\
\text { c. Accounting cycle stages at service firms (recording, } \\
\text { summarizing, reporting, and closing), } \\
\text { d. Accounting cycle stages at trading companies } \\
\text { (recording, summarizing, reporting, and closing) }\end{array}$ \\
\hline
\end{tabular}

Based on the observation and related to economic contents for high school students according to Curriculum 2013, the relevance of learning resources in the Sago Industry for economic learning can be mapped as follows table:

TABLE II. THE RELEVANCE OF LEARNING RESOURCES IN THE SAGO INDUSTRY FOR HIGH SCHOOL'S ECONOMIC LEARNING

\begin{tabular}{|c|c|c|}
\hline $\begin{array}{l}\text { Learning } \\
\text { Resources }\end{array}$ & Relevant Content for Economic Subject & Grade \\
\hline \multirow{3}{*}{$\begin{array}{l}\text { People's habits } \\
\text { in choosing } \\
\text { the kind of } \\
\text { work }\end{array}$} & The basic concept of economics & 10th \\
\hline & $\begin{array}{l}\text { Economic problems in the economic } \\
\text { system }\end{array}$ & 10th \\
\hline & $\begin{array}{l}\text { The concept of economic growth and } \\
\text { economic development and the problems } \\
\text { and how to overcome them }\end{array}$ & 11 th \\
\hline \multirow{2}{*}{$\begin{array}{l}\text { People who are } \\
\text { involved } \\
\text { in sago } \\
\text { industry }\end{array}$} & $\begin{array}{l}\text { The role of economic actors in economic } \\
\text { activities }\end{array}$ & 10 th \\
\hline & $\begin{array}{llll}\begin{array}{l}\text { Employment } \\
\text { development }\end{array} & \text { issues in economic } \\
\end{array}$ & 11 th \\
\hline \multirow{3}{*}{$\begin{array}{l}\text { Production, } \\
\text { distribution and } \\
\text { consumption } \\
\text { activities }\end{array}$} & $\begin{array}{l}\text { The role of economic actors in economic } \\
\text { activities }\end{array}$ & 10th \\
\hline & Market equilibrium and structure & 10th \\
\hline & Price index and inflation & 11th \\
\hline \multirow{3}{*}{$\begin{array}{l}\text { Financial } \\
\text { management }\end{array}$} & Management concepts & 10th \\
\hline & $\begin{array}{l}\text { The concept of basic equations of } \\
\text { accounting }\end{array}$ & 12 th \\
\hline & $\begin{array}{l}\text { Accounting cycle stages at trading } \\
\text { companies (recording, summarizing, } \\
\text { reporting, and closing) }\end{array}$ & 12 th \\
\hline
\end{tabular}

a. Source: Ref [3] 
In the economic classroom, teachers can be more creative with utilizing the source of learning from the surrounding environment for relevant learning needs. Started with make lesson plan, teacher expected to prepared a process plan and evaluation of appropriate learning, so that the ultimate goal of economic learning based on eco pedagogy can be achieved i.e. the economic literacy and environmental awareness for students.

\section{CONCLUSION}

The several sources for economic learning based on ecopedagogy in Sago Industry include: People habit in choosing the kind of work, the people who are involved in sago industry, production, distribution, and consumption activities, and financial management. These learning resources can be added in various economic contents including basic concepts of economics, economic system, economic agents, equilibrium and market structure, and also accounting concept.

\section{REFERENCES}

[1] R. McKeown, Education for sustainable development toolkit. section for education for sustainable development (ED/UNP/ESD). France: UNESCO 7 Place de Fontenoy, 75352 Paris 07 SP, 2006.

[2] H. Yunansah, Y. T. Herlambang, "Pendidikan berbasis ekopedagogik dalam menumbuhkan kesadaran ekologis dan mengembangkan karakter siswa sekolah dasar," Jurnal Pendidikan Dasar, Vol. 9. No.1 2017.

[3] R. I. Kemdikbud, Silabus mata pelajaran SMA/MA/SMK/MAK mata pelajaran ekonomi, Jakarta: Kemdikbud, 2016.
[4] D. Atmono, The Strengthening of social studies learning through ecopedagogy approach in Banjarmasin's secondary schools, Bal Proceeding 14th ADRI: International Conference Development of Science through Strengthening the Publication in Indexed Journals, 2017.

[5] S. M. Wilson, and P. Peterson, 1201 16th Street, N.W. Washington, DC 20036-3290.

[6] E. K. Kurelovic, "Advantages and limitations of usage of open educational resources in small countries," International Journal of Research in Education and Science, vol. 2, issue 1, 2016.

[7] R. Abdullah, "Pembelajaran berbasis pemanfaatan sumber belajar," Jurnal Ilmiah DIDAKTIKA, vol. XII, no. 2, 2012.

[8] K. Komalasari, Pembelajaran kontekstual (Konsep dan Aplikasi). Bandung: Refika Aditama, 2010.

[9] R. B. Okongo, G. Ngao, N.K. Rop, and W. J. Nyongesa, "Effect of availability of teaching and learning resources on the implementation of inclusive education in pre-school centers in nyamira north sub-county, Nyamira County, Kenya," Journal of Education and Practice, vol.6, no.35, 2015.

[10] B. O. Benjamin, and J. Aluko, "Teaching and learning resource availability and teachers' effective classroom management and content delivery in secondary schools in huye district, Rwanda," Journal of Education and Practice, vol.5, no.9, 2014

[11] S. M. Tsegay, "Analysis of globalization, the planet and education," international journal of environmental \& science education, vol.11, no. $18,2016$.

[12] B. Okur and Emel, "The effect of ecopedagogy-based environmental education on environmental attitude of in-service teachers," International Electronic Journal of Environmental Education, vol.5, Issue 2, 2015. 